\title{
軸方向表面き裂を有する鋳造ステンレス鋼管の破壊評価法*
}

釜谷 昌幸 ${ }^{* 1}$

\section{Fracture Analysis Procedure for Cast Austenitic Stainless Steel Pipes with an Axial Surface Crack}

\author{
Masayuki KAMAYA $^{* 1}$ \\ ${ }^{* 1}$ Institute of Nuclear Safety System, Inc. \\ Sata 64, Mihama-cho, Fukui, 919-1205 Japan
}

Since the ductility of cast austenitic stainless steel pipes decreases due to thermal aging embrittlement after long term operation, not only plastic collapse failure but also unstable ductile crack propagation (elastic-plastic failure) should be taken into account for the structural integrity assessment of cracked pipes. In the fitness-for-service code of the Japan Society of Mechanical Engineers (JSME), Z-factor is used to incorporate the reduction in failure load due to elastic-plastic failure. However, the JSME code does not provide the Z-factor for axial cracks. In this study, Z-factor for axial cracks in aged cast austenitic stainless steel pipes was derived. Furthermore, an optimized failure assessment curve (FAC) for the two-parameter method, which can also derive elastic-plastic failure load, was obtained. Then, a comparison was made for the elastic-plastic failure load obtained from different analysis procedures. It was shown that the optimized FAC as well as the obtained Z-factor could derive reasonable elastic-plastic failure loads, although the failure loads were more conservative than those obtained by the two-parameter method using FAC obtained J-value solutions. The reference stress method was found to be applicable to evaluation of the FAC. It was concluded that elastic-plastic failure loads could be derived by the Z-factor and two-parameter methods in which FAC was obtained using J-value solutions, the optimized curve and the reference stress method.

Key Words : Cast Austenitic Stainless Steel, Elastic-Plastic Fracture Analysis, Z-Factor, Failure Assessment Curve, Limit Load, Fitness-for-Service

\section{1. 緒言}

鋳造ステンレス鋼は，高い耐食性および而 SCC 性を有しており，加圧水型原子力発電プラントの 1 次系冷却水 管などで広く用いられている ${ }^{(1)}$. しかし，この材料は，熱時効により延性が低下寸るため，き裂などの欠陥が発 生した場合は，配管の破壊強度が小さくなる可能性がある(2)(3).

き裂を有する配管の破壊強度は日本機械学会発電用原子力設備規格維持規格(4)（以下，維持規格）にしたがっ て算出することができる．維持規格では，材料の延性（勒性）の程度に応じて線形破壊力学評価，弾塑性破壊力 学評価，および極限荷重評価の 3 通りの評価法が規定されている．通常，ステンレス鋼は大きな延性を有するこ とから，極限荷重評価が適用されるが，熱時効によって延性が低下した鋳造ステンレス鋼管に対しては，弾塑性 破壞力学評価を適用するよう規定されている，弾塑性破壞力学評価では， $\mathrm{J}$ 積分值（J 值）と破壞勒性曲線（J-R 曲線）を比較することで，破壊強度を算出する．維持規格ではこの評価を行う手順として， Z 係数（割増係数） を用いる方法（以下， Z 係数法と呼ぶ）と，2 パラメータ法が準備されている.

$\mathrm{Z}$ 係数法では, 弾塑性破壊力学評価による破壊荷重（以下，弾塑性破壊荷重と呼ぶ）と極限荷重の比（Z）を予 め求めておき，評価においては極限荷重と係数 $Z$ を用いることで，弾塑性破壊荷重を算出する(5). したがって， 評価において必要となる材料定数は極限荷重評価に用いる流動応力のみとなり破壊強度を簡便に算出することが

\footnotetext{
* 原稿受付 2012 年 4 月 15 日

*1 正員, (株) 原子力安全システム研究所（广919-1205 福井県美浜町佐田 64）

E-mail: kamaya@inss.co.jp
} 
Table 1 Tensile properties and parameters for Ramberg-Osgood's law ${ }^{(2)}$.

\begin{tabular}{|c|c|c|c|c|c|}
\hline \multirow{2}{*}{$\begin{array}{c}\text { Temperature } \\
\left({ }^{\circ} \mathrm{C}\right)\end{array}$} & $\begin{array}{c}\text { Yield strength } \\
(\mathrm{MPa})\end{array}$ & $\begin{array}{c}\text { Ultimate Strength } \\
(\mathrm{MPa})\end{array}$ & $\begin{array}{c}\text { Young's modulus } \\
(\mathrm{GPa})\end{array}$ & \multicolumn{2}{|c|}{ Parameters for R-O's law } \\
\cline { 5 - 6 } & & & & $\alpha$ & $n$ \\
\hline 325 & 276 & 726 & 174 & 0.965 & 4.34 \\
\hline
\end{tabular}

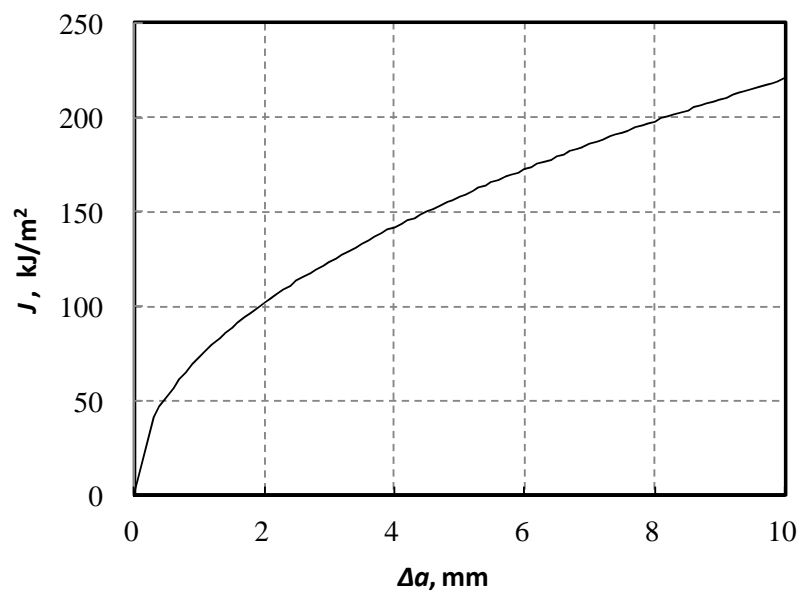

Fig.1 $J$ - $R$ curve for aged cast austenitic stainless steel ${ }^{(2)}$.

できる.しかし，現状の維持規格では軸方向き裂に対する Z 係数は準備されていない.

一方，2 パラメータ法を適用すれば軸方向き裂に対しても弾塑性破壊荷重を算出することができる．ただし， 2 パラメータ法では, 流動応力以外にも，J-R 曲線と破壊評価曲線（Failure Assessment Curve, 以下 FAC）が必要と なる ${ }^{(3)}$. 維持規格では，オーステナイト系ステンレス鋼管用に FAC が与えられており，鋳造ステンレス鋼管の破 壊荷重の算出にもこれを用いることができる．しかし，FAC は材料の変形特性（応力・ひずみ曲線）に大きく影 響を受け ${ }^{(6)}$ ，時効による延性低下（変形特性の変化）によっても変化する(3). したがって，合理的な評価のために は，時効した鋳造ステンレス鋼管に対応した FAC を用いることが望ましい.

本報では，軸方向き裂を有寸る時効した鋳造ステンレス鋼管の破壊評価を行うための Z 係数を求める. また， 併せて，時効した鋳造ステンレス鋼管に対応した FAC も検討寸る．維持規格では，2 通りの方法によって弾塑性 破壊評価に基づく破壊荷重を算出することができるが，両者が必ずしも一致するとは限らない．しかし，用いる 材料特性（ $J-R$ 曲線や応力・ひずみ曲線）や J 值の解が同じであれば，得られる破壊強度は評価法に依存しない ことが望ましい，そこで，本報では，評価法の違いによる破壊強度の変化についても考察を行う．

\section{2. 評価方法}

\section{$2 \cdot 1$ 対象とする材料および形状}

評価に用いる時効した鋳造ステンレス鋼（SCS14A）の材料特性を表 1 に示す(2).この材料特性は，維持規格の 周方向き裂に対する Z 係数を導いた際に用いられたものと等しい(4). 応力・ひずみ関係は次式の Ramberg-Osgood 則で近似されている.

$$
\frac{\varepsilon}{\varepsilon_{\mathrm{y}}}=\frac{\sigma}{\sigma_{\mathrm{y}}}+\alpha\left(\frac{\sigma}{\sigma_{\mathrm{y}}}\right)^{n}
$$

ここで， $\sigma_{\mathrm{y}}$ は耐力， $\varepsilon_{\mathrm{y}}$ は $\sigma_{\mathrm{y}} / E （ E$ はヤング率で $\left.174 \mathrm{GPa}\right)$ とした， $\alpha ， n$ は定数で，表 1 に示している．J-R 曲線は 次式で近似した。

$$
J=C_{1}(\Delta a)^{C_{2}}
$$

$C_{1}$ と $C_{2}$ は材料定数で，それぞれ時効した鋳造ステンレス鋼に相当する 73 と 0.48 とした ${ }^{(2)}$ (図 1 参照). 


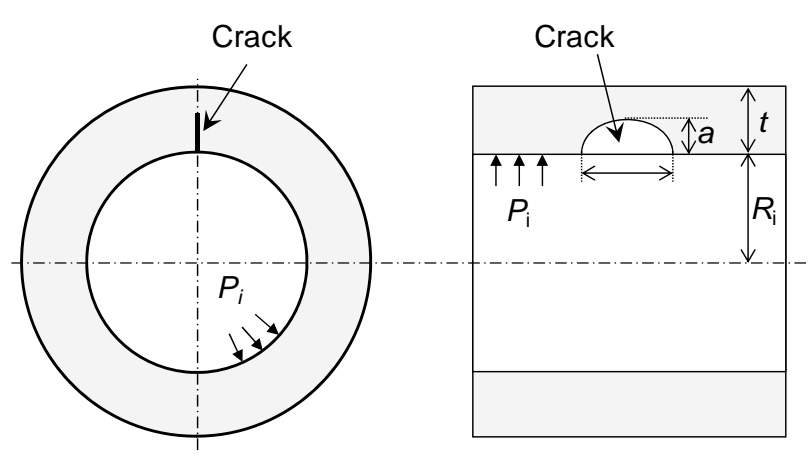

Fig.2 Geometry of cracked pipe under internal pressure.

配管およびき裂形状は図 2 のように想定した。内圧が負荷された配管の内面に半楕円形状の表面き裂が存在し ている，サポートの拘束などにより，実機においては内圧荷重下においても必ずしも軸力が期待できない，本報 では，安全側となるよう軸力は考慮しなかった， Z 係数およびFAC の検討においては，配管の平均半径 $R_{\mathrm{m}}\left(=R_{\mathrm{i}}\right.$ $+0.5 t$ ) を基準に, $R_{\mathrm{m}} / t=5 \sim 20$ の範囲で変化させた. また, 原子力発電プラントの一次冷却材管を想定し, $t=70 \mathrm{~mm}$, $R_{\mathrm{m}}=400 \mathrm{~mm}$ とした解析も行った．き裂形状は， $a / t=0.1 \sim 0.75, a / c=0.1 \sim 1.0$ の範囲で変化させた.

\section{$2 \cdot 2 \mathrm{Z}$ 係数法}

$\mathrm{Z}$ 係数法に用いられる係数 $Z$ は，極限荷重（圧力） $P_{\mathrm{L}}$ と弾塑性破壊荷重（圧力） $P_{\mathrm{EP}}$ を用いて以下の式で定義 される.

$$
Z=\frac{P_{\mathrm{L}}}{P_{\mathrm{EP}}}
$$

ここで，極限圧力は次式によって得られる(4)(7).

$$
\begin{aligned}
& P_{\mathrm{L}}=\sigma_{\mathrm{f}} \frac{t}{R_{\mathrm{m}}}\left(\frac{t / a-1}{t / a-1 / M}\right) \\
& M=\sqrt{1+\frac{1.61 c^{2}}{R_{\mathrm{m}} t}}
\end{aligned}
$$

$\mathrm{Z}$ 係数法では, $Z$ を予め準備しておくことで, 流動応力 $\sigma_{\mathrm{f}}$ とき裂形状から, 簡便に弾塑性破壊圧力 $P_{\mathrm{EP}}$ を求めるこ とができる. 流動応力は引張強さと耐力の平均，または材料規格 ${ }^{(8)}$ で定義される設計応力強さ $\mathrm{Sm}$ の 2.7 倍を用い るよう規定されている.

維持規格では, 式(4)において $R_{\mathrm{m}}$ ではなく外半径（ $R_{\mathrm{m}}+0.5 t ）$ が用いられている（根拠は明確でない)。本報で は，より一般的な $R_{\mathrm{m}}$ を用いて極限圧力を定義した.

\section{$2 \cdot 32$ パラメータ法}

2 パラメータ法を適用するには, 材料と欠陥形状に対応した FAC を求める必要がある. FAC は次式で定義され る $K_{\mathrm{r}}$ と $S_{\mathrm{r}}$ をそれぞれ縦軸，横軸にプロットすることで得られる.

$$
\begin{aligned}
& S_{\mathrm{r}}=\frac{P_{\mathrm{i}}}{P_{\mathrm{C}}} \\
& K_{\mathrm{r}}=\sqrt{\frac{J_{\mathrm{e}}}{J}}
\end{aligned}
$$

ここで， $P_{\mathrm{i}}$ は圧力で， $P_{\mathrm{C}}$ は次式で与えられる.

$$
P_{\mathrm{C}}=\sigma_{\mathrm{y}} \frac{t}{R_{\mathrm{m}}}\left(\frac{t / a-1}{t / a-1 / M}\right)
$$




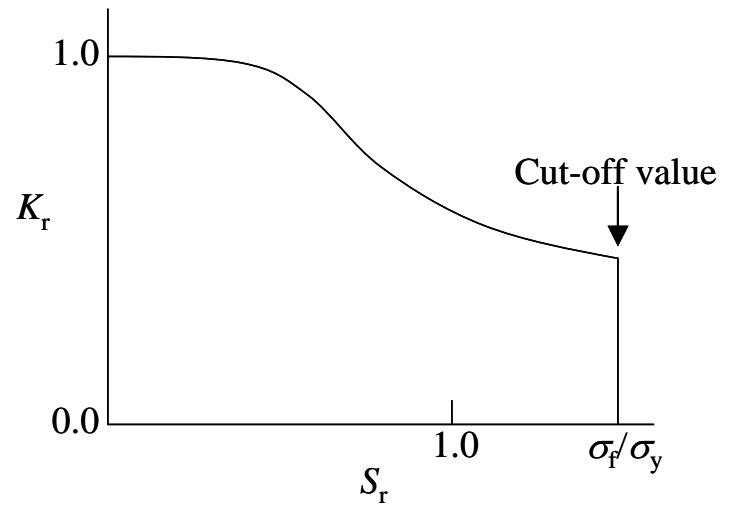

Fig.3 Schematic drawing of failure assessment curve.

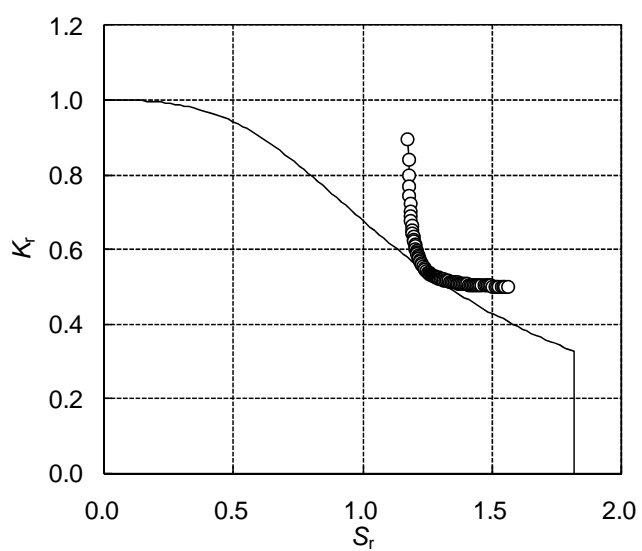

Fig.4 Critical condition in two-parameter failure assessment $\left(R_{\mathrm{m}} / t=10, t=40 \mathrm{~mm}, a / t=0.5, a / c=0.5\right)$.

式(8)は, 式(4)の流動応力を耐力 $\sigma_{\mathrm{y}}$ に置きかえたものと一致する. 維持規格では, $P_{\mathrm{C}}$ として式(8)とは異なる式を 用いているが，式(4)の極限圧力と整合させるため，ここでは式(8)を用いた．式(7)において $J$ は 積分を示し， $J_{\mathrm{e}}$ は欠陥構造物を弾性体と見なした場合に求まる弾性 J 積分で, 次式で定義される.

$$
J_{\mathrm{e}}=\frac{K^{2}\left(1-v^{2}\right)}{E}
$$

ここで， $K$ は応力拡大係数 ( $\mathrm{K}$ 值), $v$ はポアソン比で 0.3 を用いた. $\mathrm{J}$ 值と $\mathrm{K}$ 值は文献(9)の值を用いた. この文 献で $\mathrm{J}$ 值は，指数硬化則にしたがう材料の $\mathrm{J}$ 值と $\mathrm{J}_{\mathrm{e}}$ の和に補正を加えることで式(1)の変形特性に対する $\mathrm{J}$ 值を算 出しており，破壊圧力の算出に対する誤差は最大でも $6 \%$ あるるこが示されている．圧力 $P_{\mathrm{i}}$ を零から増加させ ながら座標 $\left(K_{\mathrm{r}}, S_{\mathrm{r}}\right)$ の軌跡をプロットしたものが FAC となる．ただし， $S_{\mathrm{r}}=\sigma_{\mathrm{f}} / \sigma_{\mathrm{y}}$ を限值としており，この值を カットオフ值と称する (図 3 参照).

維持規格ではオーステナイト系ステンレス鋼管の FAC として次式が与えられており, 規格上は時効した鋳造ス テンレス鋼管に対しても適用することができる.

$$
\begin{aligned}
K_{\mathrm{r}}= & \left\{g+0.1758+\frac{0.278 S_{\mathrm{r}}^{2}}{0.7396+S_{\mathrm{r}}^{2}}\right\}^{-0.5} \\
g= & 0.8242\left(1+8.0541 S_{\mathrm{r}}^{4.07}\right) \quad \text { when } S_{\mathrm{r}} \leq 1.3 \\
& 0.8242\left(87.55-82.6271 S_{\mathrm{r}}^{-1}\right) \quad \text { when } S_{\mathrm{r}}>1.3
\end{aligned}
$$

また，J值は参照応力法(6)を用いて近似的に求めることができ，その場合の FAC は次式で与えられる(10).

$$
K_{\mathrm{r}}=\left(\frac{E \varepsilon_{\text {ref }}}{\sigma_{\text {ref }}}+\frac{\sigma_{\text {ref }}^{3}}{2 \sigma_{y}^{2} E \varepsilon_{\text {ref }}}\right)^{-0.5}
$$

ここで, 参照応力 $\sigma_{\mathrm{ref}}$ は次式で定義される.

$$
\sigma_{\text {ref }}=\left(\frac{P_{\mathrm{i}}}{P_{\mathrm{L}}}\right) \sigma_{\mathrm{f}}
$$

参照ひずみ $\varepsilon_{\mathrm{ref}}$ は材料の応力・ひずみ曲線における $\sigma_{\mathrm{ref}}$ に対応するひずみとして求まる．したがって, 式(11)が適用 できれば，材料の応力・ひずみ曲線から FAC を得ることができる. 本報では，FAC を求める手段として，とく にことわりのない限り，J值を用いた直接法を適用する，そして，4 章と 5 章において，式(10)および参照応力法 を適用した場合についても比較検討する.

破壊圧力 $P_{\mathrm{EP}}$ は，次式で求まる $S_{\mathrm{r}}^{\prime}$ と $K_{\mathrm{r}}^{\prime}$ の軌跡を FAC に重ねてプロットすることで得られる. 


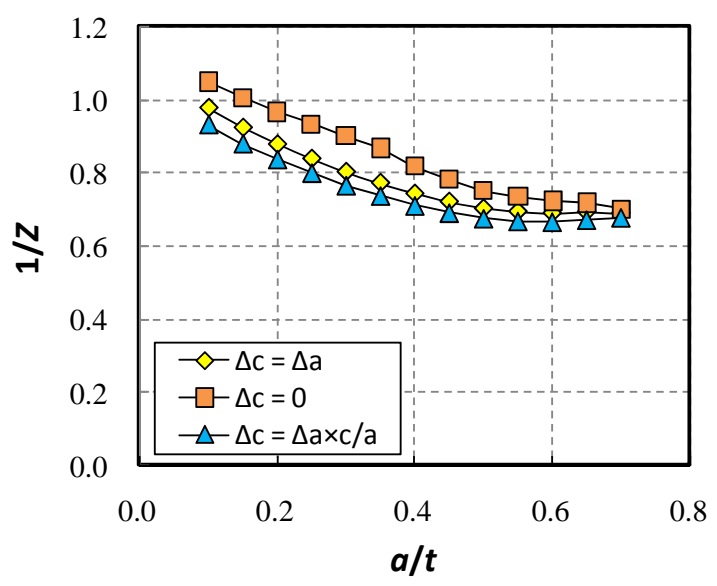

Fig.5 Effect of treatment for crack growth in the surface direction on failure strength in two-parameter method $\left(R_{\mathrm{m}} / t=10, t=40 \mathrm{~mm}, a / c=0.5\right)$.

$$
\begin{aligned}
& S_{\mathrm{r}}^{\prime}=\frac{P_{\mathrm{i}}}{P_{\mathrm{C}}} \\
& K_{\mathrm{r}}^{\prime}=\frac{K(a+\Delta a)}{\sqrt{\frac{E J(\Delta a)}{1-v^{2}}}}
\end{aligned}
$$

$J(\Delta a)$ は図 1 に示す $J-R$ 曲線上の $\Delta a$ に相当する $\mathrm{J}$ 值（破壊勒性值）で，K( $a+\Delta a)$ は深さ $a+\Delta a$ のき裂に対する $\mathrm{K}$ 值 を示し，本報では式(9)で用いたものと同じ解(9)を用いた．図 4 に FAC と材料抵抗力ーブの関係の例を示す.負荷

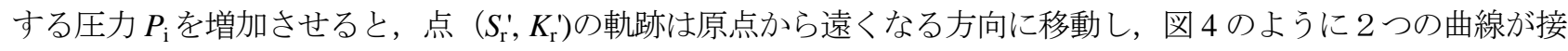
するときの $P_{\mathrm{i}}$ が破壊圧力 $P_{\mathrm{EP}}$ となる．2 つの曲線の接点の $S_{\mathrm{r}}$ 座標がカットオフ值より大きくなる場合は，破壊圧 力は $P_{\mathrm{EP}}=P_{\mathrm{L}}$ とする. 接点の $S_{\mathrm{r}}$ 座標がカットオフ值より 小さい場合は, 破壊圧力が $P_{\mathrm{L}} よ り$ 小くなることを意味 しており，接点の $S_{\mathrm{r}}$ 座標 $\times \sigma_{\mathrm{y}} / \sigma_{\mathrm{f}}$ の逆数が $\mathrm{Z}$ 係数に相当する.

\section{$2 \cdot 4$ 表面方向へのき裂進展方法}

2 パラメータ法では，式(14)によって $K_{\mathrm{r}}^{\prime}$ を算出する際，き裂を仮想的に $\Delta a$ 進展させる．このとき，表面方向へ のき裂進展 $\Delta c$ の取り扱いについては，維持規格に明確な規定がない. そこで， $\Delta a$ に対応した $\Delta c$ とて， $\Delta c=\Delta a$ とした場合， $\Delta c=0$ とした場合（表面方向にはき裂を進展させない場合），そして $\Delta c=\Delta a \times c / a$ とた場合（アス ペクト比 $a / c$ を不変とした場合）について破壊圧力を算出した. 図 5 は, 管厚 $t=40 \mathrm{~mm}, R_{\mathrm{m}} / t=10, a / c=0.5$ と した場合の， $a / t$ に対する破壊圧力の変化を示している. 破壊圧力 $P_{\mathrm{EP}}$ は，極限圧力で正規化し，式(3)にしたがっ て $1 / Z$ で表している.

図 5 において，1/Z は $a / t$ とともに小さくなる.つまり，き裂が深くなると，極限圧力に対して弾塑性破壊圧力 が低下している．そして，破壊圧力は $\Delta c=\Delta a \times c / a$ とした場合が最も小さくなった．以下の解析では， $\Delta c=\Delta a \times$ $c / a$ として破壊圧力を算出した.

\section{3. $\mathrm{Z}$ 係数の検討}

\section{$3 \cdot 1$ 幾何学条件による破壊圧力の変化}

配管とき裂形状を系統的に変化させた場合の 2 パラメータ法により得られる弾塑性破壊圧力の変化を図 6 に示 す. 正規化した破壊圧力 $1 / Z$ が 1 の場合，配管の破壊圧力が極限圧力評価と等しく，塑性崩壊による破壊を前提 とした破壊評価（極限荷重評価）が適用可能なことを意味する．配管とき裂形状による破壊圧力の変化の一般的 な傾向を調べるため, 中間的な值となる $R_{\mathrm{m}} / t=10, t=40 \mathrm{~mm}, a / \mathrm{t}=0.5, a / c=0.5$ を基本条件に各パラメータを変 


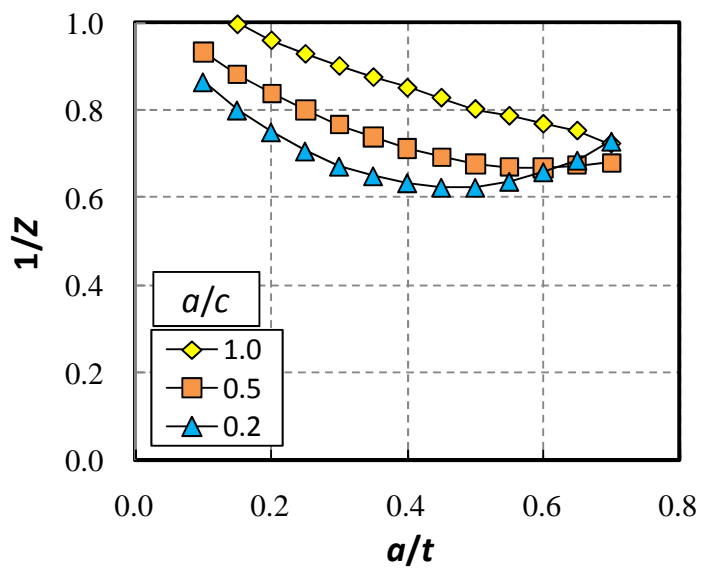

(a) Effect of crack depth

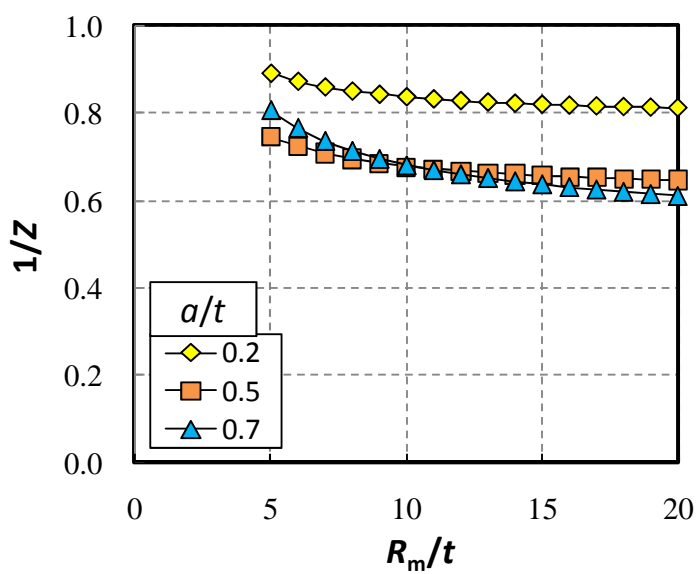

(c) Effect of $R_{\mathrm{m}} / t$

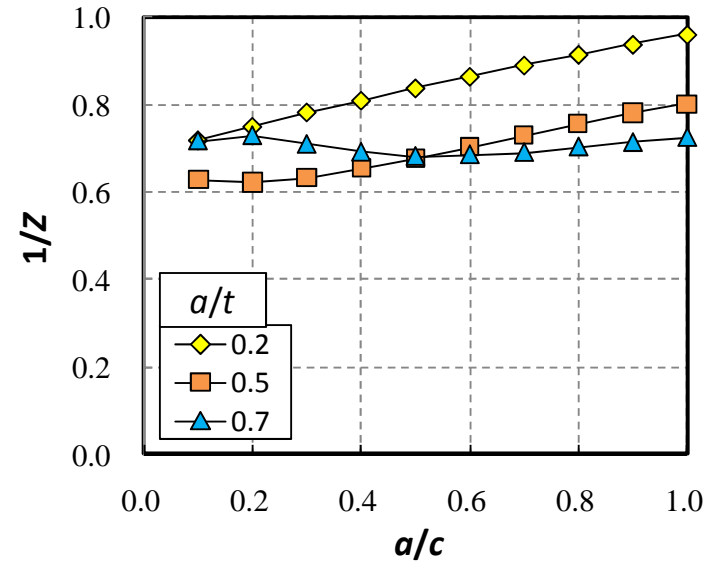

(b) Effect of aspect ratio

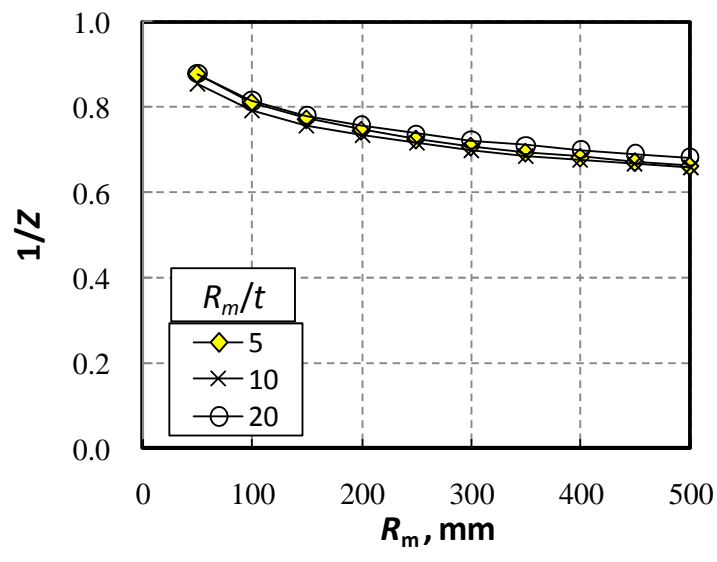

(d) Effect of pipe radius

Fig.6 Normalized failure strengths under various geometrical conditions (basic condition: $R_{\mathrm{m}} / t=10, t=40 \mathrm{~mm}, a / t=0.5, a / c=0.5$ ).

化させた．図 6(a)に示した $1 / Z$ と a/t の関係においては，き裂が浅い場合 $1 / Z$ は 1 に近く，き裂が深くなると $1 / Z$ が小さくなる傾向を示した．ただし，a/c が小さい場合は，単調な減少ではなかった．また，図 6(b)に示す $a / c に$ 対する変化では，大局的には増加する傾向にあるが，き裂が深くなると単調な増加とはならなかった，一方，図 6(c)および図 6(d)に示すように, $R_{\mathrm{m}} / t$ および $R_{\mathrm{m}}$ に対しては単調減少となった.

図 6 の結果より，Z 係数はき裂形状などによって複雑に変化していることがわかる．現在の維持規格では，こ れらの複雑な変化を安全側に包絡することで, $\mathrm{Z}$ 係数を $D_{0}\left(=2 R_{\mathrm{m}}+t\right)$ の関数式として与えている. $D_{0}$ のみの関数 とした場合，き裂が小さく，その影響が無視できるような場合にも，弾塑性破壊圧力の低下を考慮することにな る. 一方，朝田ら ${ }^{(5)}$ は， Z 係数を $D_{0}$ と a/t の関数とすることで，保守性の小さい，より合理的な $\mathrm{Z}$ 係数を提案し ている.

\section{$3 \cdot 2 \mathrm{Z}$ 係数の導出}

2 パラメータ法から得られる $Z$ を包絡するような Z 係数の式の導出を試みる. $Z$ の $R_{\mathrm{m}} / t$ に対する変化は相対的 に小さく, $R_{\mathrm{m}} / t$ に対して単調増加した. 原子力発電プラントにおいて評価の対象となる配管の $R_{\mathrm{m}} / t$ は 10 を超え ることはないことから， $R_{\mathrm{m}} / t=10$ として，朝田らと同じく，Z 係数を $D_{\mathrm{o}}$ と $a / t$ の関数として定義する.

図 7 は $a / c=0.5$ とした場合の $Z$ と a/t の関係を示寸. Z は配管径が大きくなるにしたがって増加しているが, 図 6(a)にも示したように $a / t$ に対して単調な変化とはならなかった. 安全側の評価のためには，これらの $Z$ を包絡す る式を導出寸る必要がある，a/tが小さいときは， Z は $a / t$ に対して直線的に増加している，そこで， Z が直線的に 変化している $a / t$ の範囲（図 7 に図示した範囲）のデータに対して回帰直線（図 7 に実線で表示）を得た. 図 8 
Used for deriving Z-factor equation

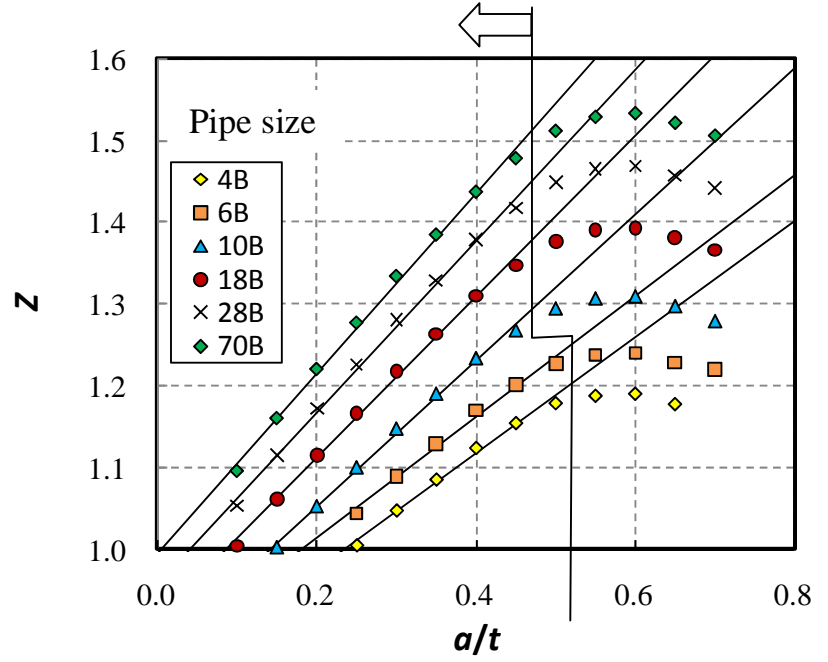

Fig.7 Failure strengths under various pipe diameters $\left(R_{\mathrm{m}} / t=10, a / c=0.5\right)$.

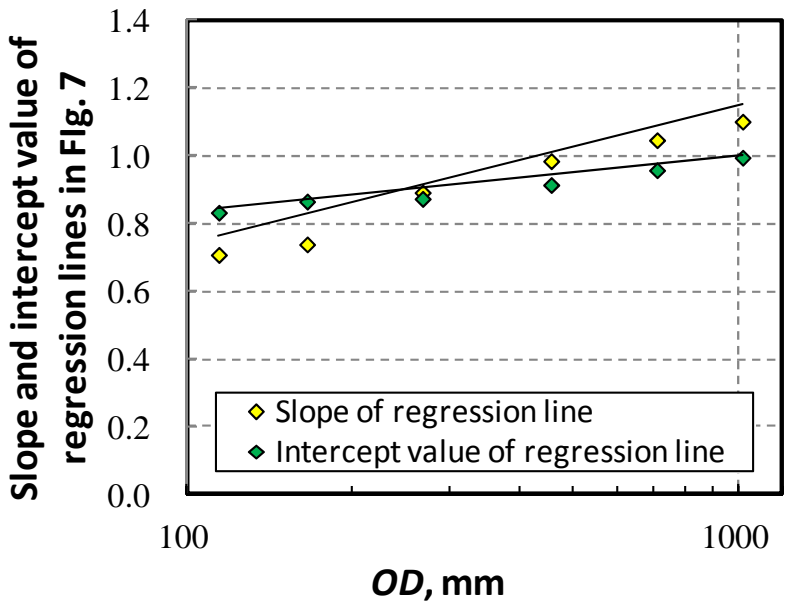

Fig.8 Change in slope and intercept of regression lines shown in Fig. 7.

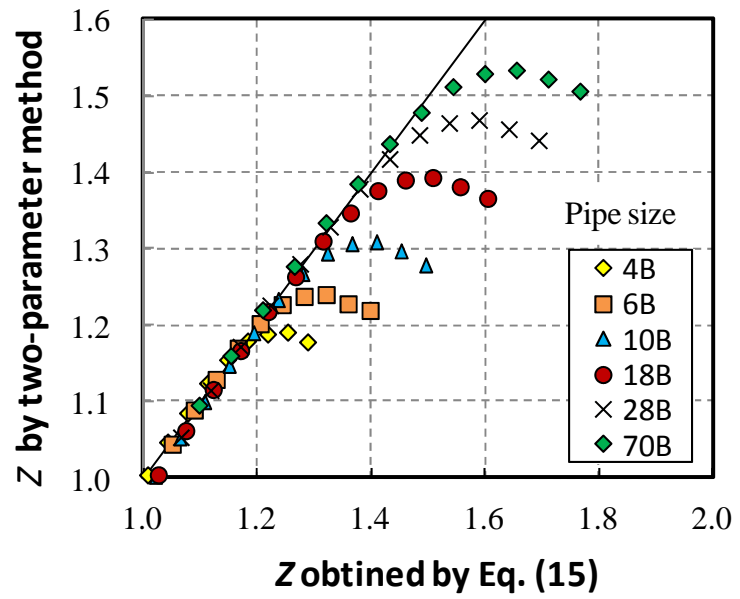

Fig.9 Relationship between the estimated $Z$ and those obtained by two-parameter method $\left(R_{\mathrm{m}} / t=10, a / c=0.5\right)$.

はこれらの回帰直線の傾きおよび切片と，配管径の関係を示している。そして，これらの関係を近似することで 次式を得た。

$$
Z=0.493+0.163 \log \left(D_{\mathrm{o}}\right)+\left\{-0.192+0.435 \log \left(D_{\mathrm{o}}\right)\right\}\left(\frac{a}{t}\right) \quad(\text { for } a / c=0.5)
$$

ここで, $D_{0}$ の単位は $\mathrm{mm}$ としている.この式を用いて, 図 7 の条件で Z 係数を求めた結果との比較を図 9 に示す. 全ての条件において，2 パラメータ法による Z をほぼ安全側に包絡できている.

図 6(b)に示したように，Zは $a / c$ にも依存した。そこで，上記と同様の手順で， $a / c=0.2$ および 1.0 に対する Z 係数を算出, 近似することで, 次式を得た.

$$
\begin{aligned}
& Z=0.425+0.191 \log \left(D_{\mathrm{o}}\right)+\left\{-0.0844+0.624 \log \left(D_{\mathrm{o}}\right)\right\}\left(\frac{a}{t}\right) \quad(\text { for } a / c=0.2) \\
& Z=0.411+0.168 \log \left(D_{\mathrm{o}}\right)+\left\{0.0453+0.214 \log \left(D_{\mathrm{o}}\right)\right\}\left(\frac{a}{t}\right) \quad(\text { for } a / c=1.0)
\end{aligned}
$$




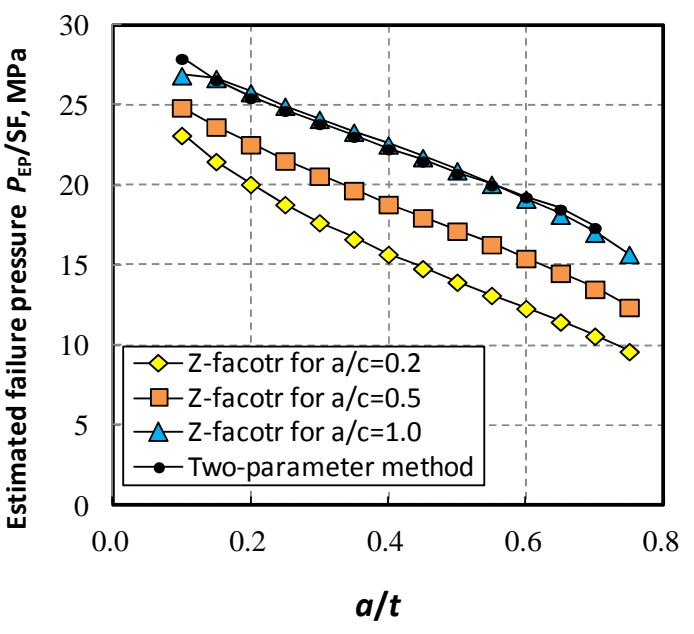

(a) Crack shape $a / c=1.0$

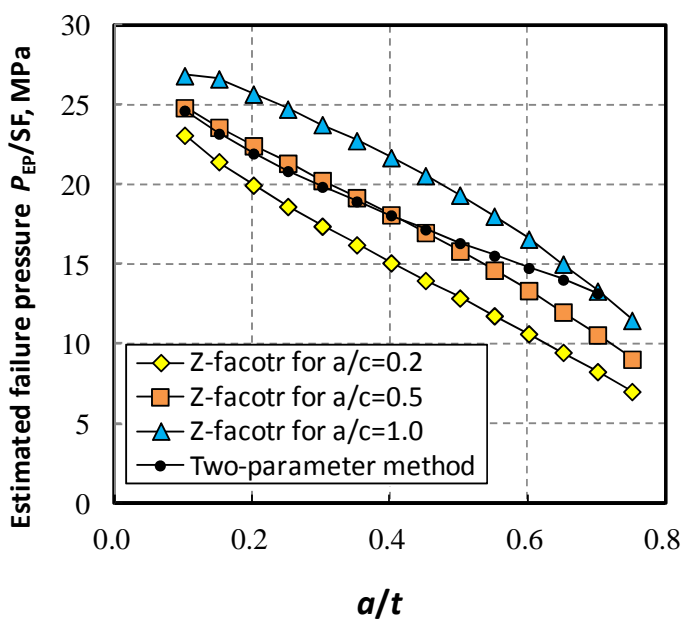

(b) Crack shape $a / c=0.5$

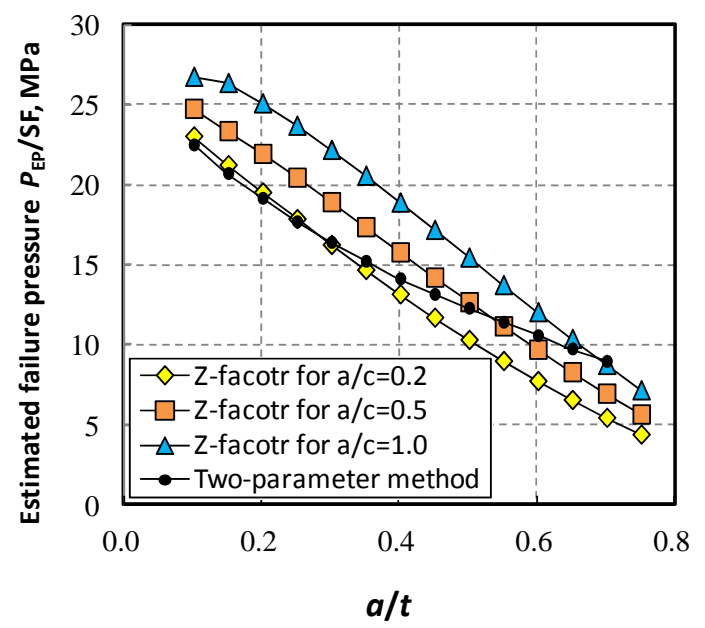

(c) Crack shape $a / c=0.2$

Fig.10 Failure strengths obtained using Z-factor and two-parameter methods ( $t=70 \mathrm{~mm}, R_{\mathrm{m}}=400 \mathrm{~mm}$ ).

これらの式を用いて, 一次冷却材管を想定した $t=70 \mathrm{~mm}, R_{\mathrm{m}}=400 \mathrm{~mm}$ の配管の破壞圧力を算出した. 図 10 に, アスペクト比 $a / c=0.2 ， 0.5$ ，および 1.0 に対する破壊圧力 $P_{\mathrm{EP}}$ と a $/ t$ の関係を示す. ここで, 安全率 $S F$ は許容状態 $\mathrm{A}$ および B に対応寸る 3.0 としている. また, 比較のため 2 パラメータ法による破壞圧力も示した. 2 パラメー 夕法による破壊圧力を基準に考えると, $a / c=1.0$ に対応する式(17)は危険側となる場合が多かった. 一方, $a / c=0.2$ に対する式(16)は，2 パラメータ法の破壊圧力に対してほぼ安全側となった.

\section{FAC の検討}

\section{$4 \cdot 1$ 幾何学条件による FAC の変化}

式(6)および式(7)の定義より, 材料定数が同じ場合でも, FAC はき裂や配管形状によって変化する. 図 11 に $R_{\mathrm{m}} / t$ $=10, a / t=0.5$ および $a / c=1.0$ を基本条件として，a/c を 0.1 から 1.0 まで 0.1 刻みで増加させた場合， $a / t$ を 0.1 か ら 0.75 まで 0.05 刻みで増加させた場合, および $R_{\mathrm{m}} / t$ を 5 から 20 まで 1 刻みで増加させた場合の FAC をそれぞ れ示寸. FAC は，a/c が大きくなるほど，また $a / t$ が小さくなるほど，そして $R_{\mathrm{m}} / t$ が大きくなるほど原点に近くな る方向に変化している. 評価の手順にしたがえば, 原点に近い FAC の方が破壊圧力を安全側に評価することにな る.したがって，a/c が大きくかつ $a / t$ が小さい，そして $R_{\mathrm{m}} / t$ が大きい条件に対する FAC を用いることで，き裂 および配管形状の影響を安全側に評価することができる. 


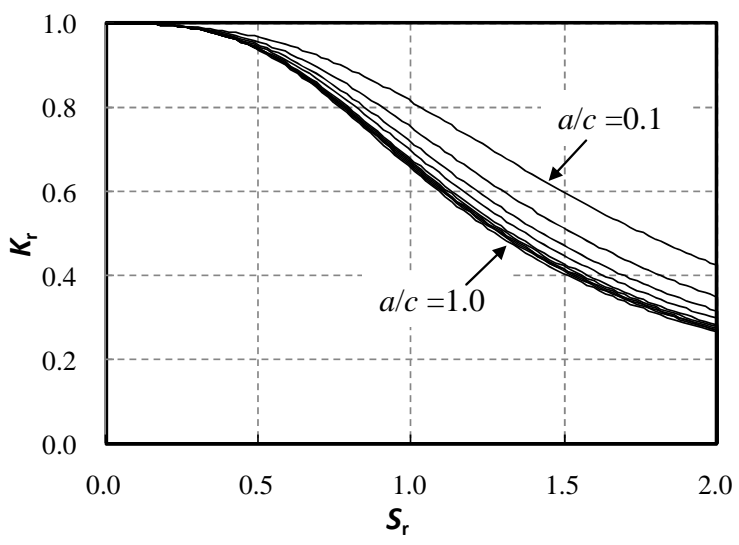

(a) Effect of crack shape

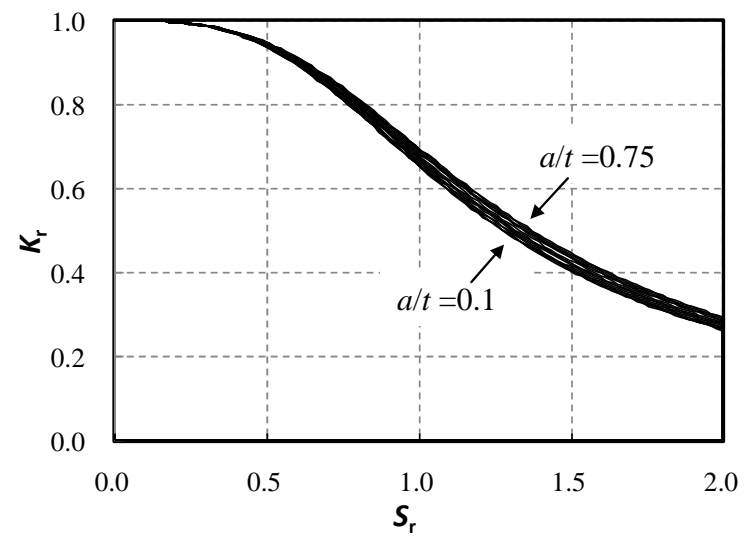

(b) Effect of crack depth

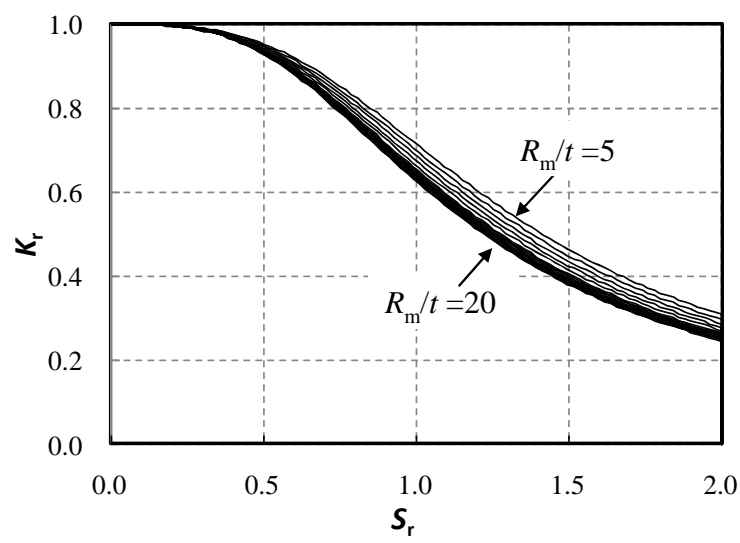

(c) Effect of $R_{\mathrm{m}} / t$

Fig.11 Failure assessment curves under various conditions (basic condition: $R_{\mathrm{m}} / t=10, t=40 \mathrm{~mm}, \mathrm{a} / \mathrm{t}=0.5 \mathrm{a} / \mathrm{c}=1.0$ ).

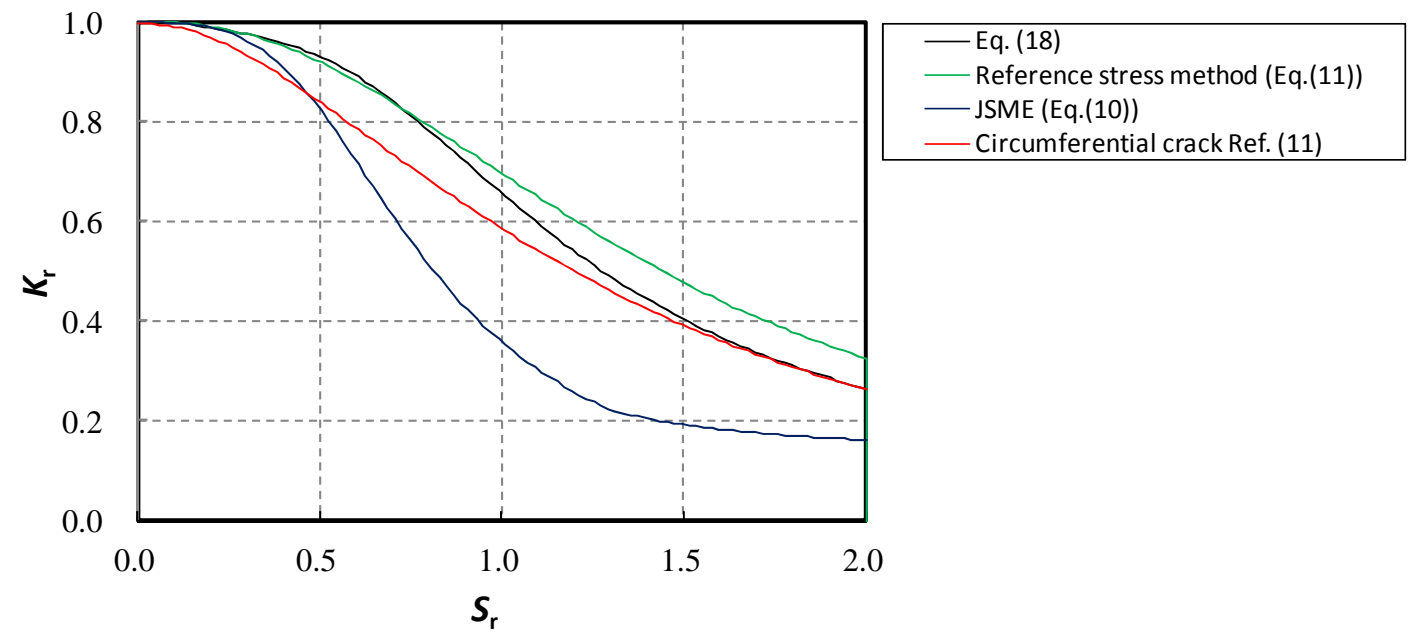

Fig.12 Comparison of failure assessment curves obtained by different procedures.

\section{$4 \cdot 2$ 維持規格に用いる FAC の検討}

き裂や配管の形状に対応した FAC を予め準備しておけば，破壊評価において J 值を用いて FAC を求める必要 がなくなる. 評価の簡便さの点からは, 現在の維持規格のように幾何学条件に関係なく, 材料毎に FAC を定義す ることが望ましい，そこで， Z 係数と同じく $R_{\mathrm{m}} / t$ を実機に対する安全側の值である $R_{\mathrm{m}} / t=10$ として FAC を求め 


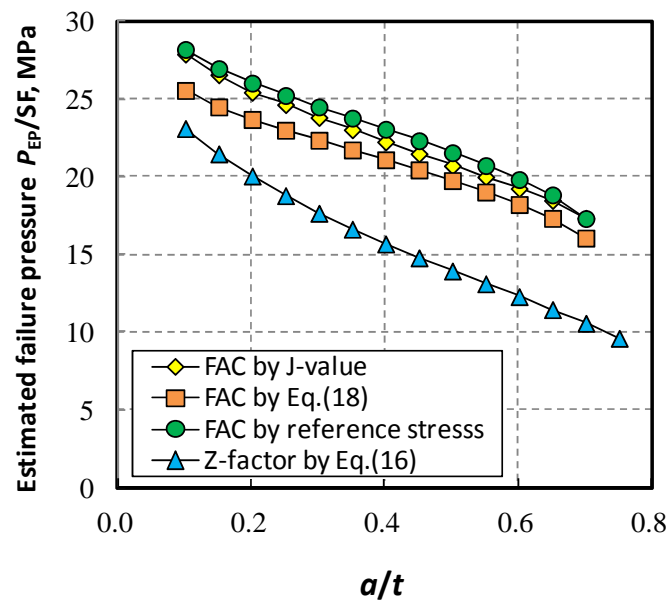

(a) Crack shape $a / c=1.0$

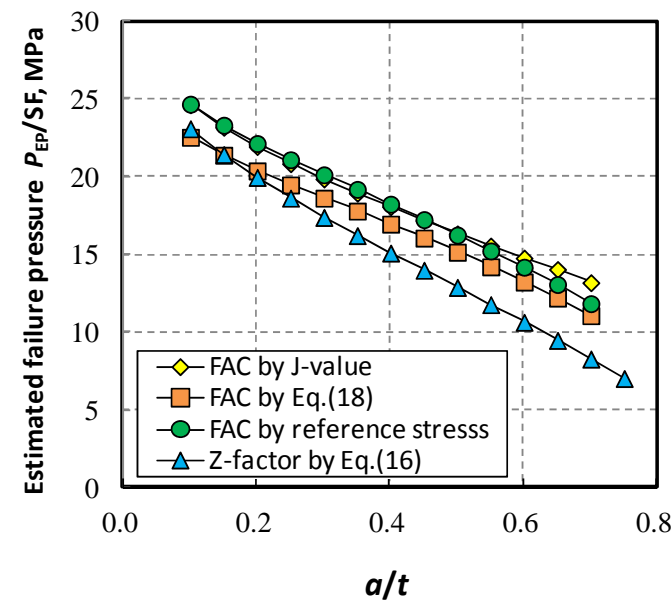

(b) Crack shape $a / c=0.5$

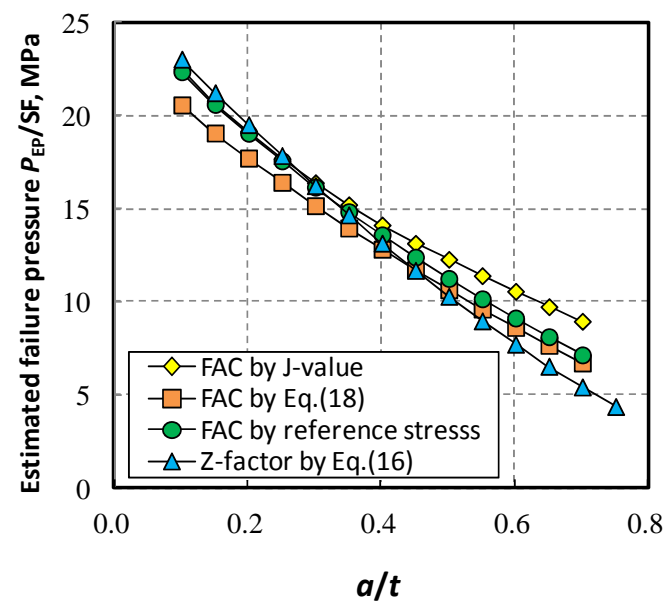

(c) Crack shape $a / c=0.2$

Fig.13 Failure strength derived using various procedures $\left(t=70 \mathrm{~mm}, R_{\mathrm{m}}=400 \mathrm{~mm}\right)$.

た. また,$a / c$ も安全側となるよう,$a / c=1.0$ とした，つまり，図11(b)の FAC の最も内側の点を包絡する曲線が 求めるべき FACで，それを近似することで次式を得た.

$$
K_{\mathrm{r}}=\left(0.949+0.574 S_{\mathrm{r}}-1.46 S_{\mathrm{r}}^{2}+2.26 S_{\mathrm{r}}^{3}\right)^{-0.5}
$$

図 12 に式(18)による FAC，および維持規格のオーステナイト系ステンレス鋼管用の式(10), 参照応力法を用いて 導出された式(11)の FAC を示す.オーステナイト系ステンレス鋼管用の式(10)は，式(18)と大きく異なっており， 鋳造ステンレス鋼管に用いるには過度に安全側であることがわかる．材料が脆化（硬化）することによって同じ $S_{\mathrm{r}}$ に対する塑性ひずみが相対的に小さくなり J值は減少する. 結果として $S_{\mathrm{r}}$ に対する $K_{\mathrm{r}}$ が増加する方向に変化し, FAC が式(10)より外側となった ${ }^{(3)}$. 参照応力法による FAC は式(18)より危険側となったが，その差は相対的に小 さかった．また，同様の手順で周方向き裂に対して求められた FAC ${ }^{(11)}$ は式(18)よりも安全側となっている.

\section{5. 一次冷却材管の破壊評価}

以上の結果より，軸方向き裂の弾塑性破壊圧力を算出する手順としては式(16)の Z 係数を用いる Z 係数法と 2 パラメータ法が考えられる.ささら，2 パラメータ法に用いる FACを得る手段としては，幾何学形状に対応した $\mathrm{J}$ 值解を用いて式(6)および(7)により直接求める方法, 式(18)による方法, そして参照応力法を適用した式(11)によ る方法が考えられる. そこで，これらの方法を用いて，一次冷却材管を想定した $t=70 \mathrm{~mm}, R_{\mathrm{m}}=400 \mathrm{~mm}$ の配管 
Table 2 Summary of required data and accuracy of each assessment procedure.

\begin{tabular}{|c|c|c|c|c|c|c|}
\hline \multirow{2}{*}{\multicolumn{2}{|c|}{ Assessment procedure }} & \multicolumn{4}{|c|}{$\begin{array}{c}\text { Required data } \\
\text { (O: necessary, } \times \text { :not necessary) }\end{array}$} & \multirow[b]{2}{*}{ Accuracy } \\
\hline & & $\begin{array}{l}\text { Flow } \\
\text { stress }\end{array}$ & $\begin{array}{l}J-R \\
\text { curve }\end{array}$ & $\begin{array}{l}\text { Stress- } \\
\text { strain } \\
\text { curve }\end{array}$ & $\begin{array}{l}\text { J-value } \\
\text { solutions }\end{array}$ & \\
\hline \multicolumn{2}{|c|}{ Z-factor method } & O & $x$ & $x$ & $x$ & $\begin{array}{c}\text { Most } \\
\text { conservative }\end{array}$ \\
\hline \multirow{3}{*}{$\begin{array}{l}\text { Two- } \\
\text { parameter } \\
\text { method }\end{array}$} & $\begin{array}{l}\text { Proposed FAC } \\
\text { (Eq. (18)) }\end{array}$ & O & O & $x$ & $x$ & $\begin{array}{c}\text { Generally } \\
\text { conservative }\end{array}$ \\
\hline & $\begin{array}{c}\text { Reference } \\
\text { stress method } \\
\text { (Eq. (11)) }\end{array}$ & $\mathrm{O}$ & O & O & $x$ & Good \\
\hline & $\begin{array}{l}\text { J-value } \\
\text { (Ref. (9)) }\end{array}$ & O & O & O & O & Base \\
\hline
\end{tabular}

の破壊圧力を算出した. 図 13 に，アスペクト比 $a / c=0.2,0.5$ および 1.0 に対する破壊圧力 $P_{\mathrm{EP}}$ と $a / t$ の関係を示 す.ここで，安全率 SF は 3.0 としている.

評価としては，J值解を用いて得られた FACによる 2 パラメータ法が，弾塑性破壊力学評価に基づく厳密な解 析結果を与えると考えることができる. これを基本解とすると， Z 係数法による破壊圧力は基本解よりも保守側 の評価となる傾向を示した．また，式(18)の FAC を用いた場合も相対的に保守側の破壊圧力となっている．これ らの評価では, $Z$ または FAC に対する $a / c$ と $a / t$ の影響を安全側に包絡しているため, 全ての条件において破壊圧 力が基本解と一致するとは限らない。 また，評価時に $J-R$ 曲線が必要となる式(18)の FAC を用いる方法が，Z 係 数法よりも基本解に近い值となっていることは合理的である.

参照応力法による FAC は，式(18)より危険側となったが，算出された破壊圧力については，基本解と同等とな り，極端に危険側とはならなかった。実際の評価において安全率が考慮されることを考えると，軸方向き裂を有 する時効した鋳造ステンレス鋼管に対しては，参照応力法は適用できると考えられる.

評価に必要な材料特性， $\mathrm{J}$ 值， $\mathrm{K}$ 值解と評価法，および得られる精度の関係をまとめると表 2 のようになる. 本報の検討では，いずれの方法を用いても妥当な評価を行うことができた．より多くの材料データを用いること で，評価精度が向上する（基本解に近づく）ことが期待できる.

\section{6. 結}

本報では，維持規格において，軸方向き裂を有する時効した鋳造ステンレス鋼管の破壊評価を行うために必要 となる Z 係数および FACについて検討した．また，評価法の違いによる破壊強度の変化についても考察した．結 果は以下のように要約できる.

（1） 2 パラメータ法において, 評価時の仮想的な深さ方向のき裂進展 $\Delta a$ に対応する表面方向の進展 $\Delta c$ は, $\Delta c$

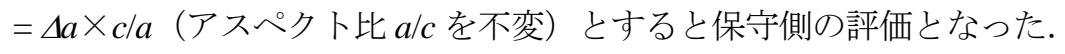

（2） Z 係数は， $R_{\mathrm{m}} / t$ ，および $R_{\mathrm{m}}$ に対しては単調増加となったが $a / c$ および $a / t$ に対しては複雑に変化した. こ れらの Z 係数を包絡近似して得られた式(16)を用いることで, 表 1 の特性を有する材料に対して, 種々の き裂形状に対する一次冷却材管の破壊圧力がほぼ安全側に評価できた.

（3）式(18)の FAC を用いた 2 パラメータ法により，き裂や配管形状に関係なく，鋳造ステンレス鋼管の破壊 圧力を安全側に評価できる. 
（4）参照応力法は，軸方向き裂を有する時効した鋳造ステンレス鋼管に対して適用できる.

（5）弾塑性破壊圧力を算出する手順として 4 通りの方法が示された. 実機の評価においては，より多くの材料 データを同定し，それに対応した評価方法を選択寸ることで，評価精度を向上させることができる.

\section{文献}

(1) 桑野寿, ”構造材料の経年劣化の機構と寿命予測（2 相ステンレス鋼の時効脆化と寿命予測）”, まてりあ, Vol. 35(1996), pp.747-752.

(2) Koyama, K., Hojo, K., Muroya, I. and Kawaguchi, S., "Z factors for Aged Cast Duplex Stainless Steel Pipes and Welds", ICONE-7477, 7th International Conference on Nuclear Engineering, (1999).

（3）釜谷昌幸, “欠陥構造物の破壊強度に及ぼす塑性ひずみの影響”, 日本機械学会論文集A編, Vol. 76, No. 762 (2010), pp.205-214.

（4）日本機械学会, 発電用原子力設備規格維持規格, JSME S NA1-2008 (2008), 日本機械学会.

(5) 朝田誠治, 板谷雅雄, 三浦直樹, 町田秀夫, ”日本機械学会維持規格における弾塑性破壊力学評価法に用いる割増し 係数（Z 係数）の開発”, 日本機械学会論文集A編, Vol. 77, No. 779 (2011), pp.1135-1143.

（6）釜谷昌幸，町田秀夫，“参照応力 J 積分簡易解析法の破壊評価曲線評価への適用性の検討”, 日本機械学会論文集 $\mathrm{A}$ 編, Vol. 75, No. 751 (2009), pp.333-342.

(7) Folias, E. S., An axial crack in a pressurized cylindrical shell, Int. J. Fracture Mech., Vol.1 (1965), pp.104-113.

（8）日本機械学会, 発電用原子力設備規格材料規格, JSME S NJ1-2011 (2011), 日本機械学会.

(9) Kamaya, M., “J-integral solutions for surface cracks inside pipes under internal pressure”, Journal of Solid Mechanics and Materials Engineering, Vol. 6, No. 8 (2012), pp.871-885.

(10) Ainsworth, R. A., "The assessment of defects in structures of strain hardening material", Engineering Fracture Mechanics, Vol.19 (1984), pp.633-642.

(11) Kamaya, M. and Hojo, K., "Elastic-plastic fracture mechanics analysis of cast stainless steel pipes (comparison of Z-factor, two-parameter and J-T methods)", Proceedings of ASME PVP2012 (2012), Paper no. PVP2012-78687. 